\title{
Rebuilding of coils of screw conveyors with chromium cast iron hard layer
}

\begin{abstract}
The purpose of the work was to determine the possibility of rebuilding of the screw coils upper surface of a screw conveyors welded previously with chromium cast iron. The variant of surfacing directly on the residues of the hard layer and with the buffer layer was considered. The technology of hardfacing the coils after removal of the hardening up-

per layer and the technology of welding of new elements with the use of EnDOtec DO*390 flux cored wire has been developed to provide a NanoAlloy structure with boron nanocarbons in the iron matrix.
\end{abstract}

Keywords:

screw conveyor; rebuilding surfacing

\section{Introduction}

In screw conveyors, as a result of friction of the displaced bulk material transported by means of a screw surface rotating around its own axis, the face (upper) and side face of the screw conveyor (coils of the screw surface wound on the screw shaft) are consumed. The capacity of the conveyor is significantly dependent on the wear of the front face of the screw coil. In order to reduce the wear of the worm exploited in the abrasive wear conditions in the building materials industry, mining industry, etc., the side and top surfaces of the coils are most often coated with chromium cast iron.

The purpose of the work was to determine the possibility of regenerative surfacing of the upper surface of screw coils of the screw conveyor with residues of the hard layer welded previously with chromium cast iron, operated in metal-mineral abrasion conditions and development of the powder coating technology based on nanomaterials, for high abrasion resistance. A powder wire EnDOtec DO*390 [1] was selected for the tests.

The subject of the research were screw coils (basic material - S355JR sheet steel, $8 \mathrm{~mm}$ thick), productively welded with chromium cast iron EN 14700: Fe15, martensitic structure + chromium carbide. The thickness of the padding layer deposited on the upper surface of the coils was $8.1 \div 9.2 \mathrm{~mm}$, and on the lateral surface of the screw coils, $3.5 \div 6.5 \mathrm{~mm}$. On the lateral surface of the screw coils and on the upper surface, cracks characteristic for layers welded with the chromium cast iron were found. The width of these cracks ranged from $<0.05 \mathrm{~mm}$ to $\leq 0.50 \mathrm{~mm}$. On the upper surface of some coils, there was also a detachment of the padding layer with a depth of up to $11 \mathrm{~mm}$ and a length of up to $30 \mathrm{~mm}$, as well as gas pores up to $12.2 \times 4.9 \mathrm{~mm}$ and depth up to $3.9 \mathrm{~mm}$ (Fig. 1).

\section{Welding filler materials with nanopowders}

In the production of flux cored wires coating wires and metallizing powders, hardly fusible nanopowders and those with high hardness, such as tungsten and chromium, are used in some cases. They are hard to fragment and their medium and large fractions are used (in case of tungsten with an average size of $200 \div 500 \mathrm{~nm}$ ), referred to as ultra-dispersive materials [2]. The grain dimensions and nature of the crystallized metal are influenced by the technological conditions of surfacing, fractional composition and microstructure of the powder constituting the filler material, which is confirmed by studies of the impact of carbide compositions with dimensions of nanostructured materials introduced into the charge of powder wires [3]. The use of charge materials containing nanowires carbides in flux cored wires for arc welding leads to the fragmentation of the padding structure and a more even distribution of alloying elements. Weld deposit of flux cored wires, whose charge contains nano-sized carbides, has a higher resistance to heat and wear on metal-to-metal

dr hab. inż. Eugeniusz Turyk - Institute of Welding, Gliwice, Poland;

prof. dr hab. inż. Igor Aleksandrowicz Riabcew - E.O. Paton Electric Welding Institute of the National Academy of Sciences, Kiev, Ukraine; mgr inż. Marcin Melcer - Messer Eutectic Castolin Sp. z o.o., Gliwice, Poland; 

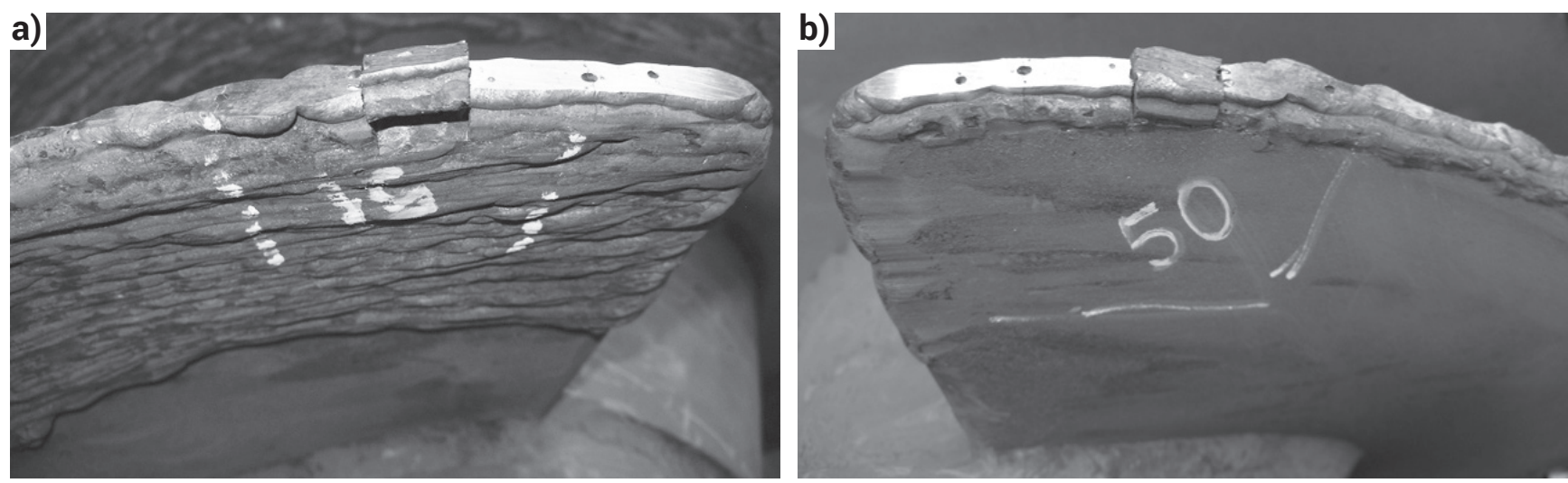

Fig. 1. Torn off piece of surfaced layer on the fifth coil of the screw, view from the side: a) welded lateral screw surface; b) non welded lateral screw surface

sliding friction. In the case of plasma-powder welding, powder of fine fractions $(40 \div 125 \mathrm{~nm})$ melts in the arc and significantly overheats in the welding pool, and when it cools, large dendrites grow. At the content of large fractions $200 \div 250 \mathrm{~nm}$ or $315 \div 400 \mathrm{~nm}$, the structure of the padding layer is fragmented [4]. The operational properties of machine parts with nano coatings depend on their nanometric structure.

For surfacing parts of machines which operate in metal-mineral and metal-mineral-metal abrasion and moderate impact conditions, an EnDOtec DO $\$ 390$ powder wire is recommended (classification EN 14700: ZFe16), which provides a NanoAlloy structure with nanocarbides in the iron matrix [1]. In the case of standard materials used for welding of layers operated under frictional conditions, containing tungsten carbides with irregular shapes, arranged in a matrix with a lower hardness, the abrasive wear mechanism is associated with the chipping of carbides from the soft matrix. In the case of EnDOtec DO $\$ 390$ weld metal, microstructure tests have shown highly dispersive microand nanostructure, in which the particles of high-volume carbides (MC), boron carbides $\mathrm{M} 23(\mathrm{BC})$ and borides $\mathrm{M} 2 \mathrm{~B}$ are distributed in a fine-grained iron matrix [5]. The same abrasive medium, under the same wear conditions, is not capable of "attacking weak spots" of the EnDOtec DO*390N metal wire. The structure of the welded layer allows obtaining a high resistance to abrasive wear of the metal-mineral and metal-mineral-metal type. Relative abrasion resistance rate of EnDOtec DO $390 \mathrm{~N}$ wire alloy is 14.40 in relation to HARDOX 400 steel (indicator $=1$ ), whereas for the EnDOtec DO*33 metal alloy (chromium cast iron with the addition of boron and niobium) is 7.92 [6]. The use of EnDOtec DO*390N wire, in the case of sinter crusher elements working in the conditions of metal-mineral abrasion and moderate impact, ensured extending the service life by $245 \%$ [1].

Table I. Sets of cored wires for hardfacing test plates

\section{The process and results of the surfacing tests}

The technological trials of surfacing of the used upper surface of screw coils of the screw conveyor with residues of the hard layer, without a buffer layer and with a buffer layer, ended with a negative result due to the occurrence of unacceptable tears in the padding layer on the upper surface of the coil of tested worm and in the buffer layer. Subsequent padding tests concerned the case of regeneration after removing the residues of the hard layer from the upper surface of the screw coils. In order to check the possibility of repairing the surface of the conveyor after removing the hard layer from the front face of the screw coil, determine the thickness of the layers and the hardness of the pad weld made of one, two, three and four layers, the attempts of surfacing of plates simulating conveyor coils and testing of padded layers were carried out. The surfacing tests were carried out on flat plates made of S355JR steel, size $8 \times 250 \times 120 \mathrm{~mm}$, stiffened on one side on a length of $250 \mathrm{~mm}$ with a steel flat bar. A side layer, a buffer layer and an upper working layer (Fig. 2; beads 1 to 4), were padded on the panels using sets of additional materials according to table I.

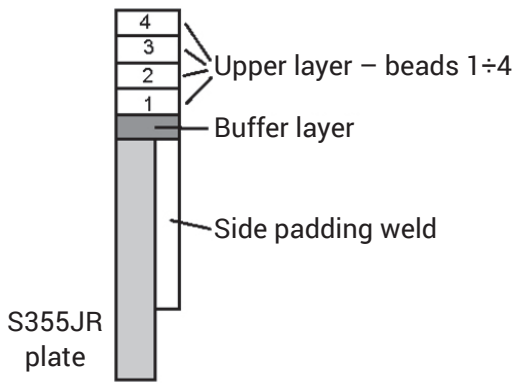

Fig. 2. Layer arrangement during the simulation of the conveyor screw repair after removal of the hard layer from the front face of the screw coil

\begin{tabular}{|c|c|c|c|}
\hline Series of trials ${ }^{\left.{ }^{*}\right)}$ & Side surface padding weld & Buffer layer & Upper layer \\
\hline 1 & HARDFACE HC-O *2) & EnDOtec DO*02 & EnDOtec $\mathrm{DO} * 390 \mathrm{~N}$ \\
\hline 2 & EnDOtec $\mathrm{DO} * 390 \mathrm{~N}$ & EnDOtec DO*02 & EnDOtec DO*390N \\
\hline \multicolumn{4}{|c|}{$\begin{array}{l}\text { Designation: } \\
\star_{11)} \text { - For each set, plates with the upper layer surfaced with one, two, three and four-beaded plates were made, marking plates with the number of the set } \\
\text { and the number of beads of the top layer; } \\
\star_{22} \text { - HARDFACE HC-O [7] wire was used to provide the padding layer of chromium cast iron, modeling the production padding weld of the side surface } \\
\text { of the screw coils. }\end{array}$} \\
\hline
\end{tabular}


The technological conditions of mechanized surfacing in the flat position for the above filler materials and the data on the thickness of the padded layers selected during the tests are provided in tables $11 \div \mathrm{V}$.

A total of 12 runs were laid on the width of $40 \mathrm{~mm}$ on the side surface with self-shielding flux cored wire of the HARDFACE HC-O grade. The thickness of the padded layer was $4.5 \div 5.0 \mathrm{~mm}$. Cracks with a width of $\leq 0.3 \mathrm{~mm}$ were found in the padded layer.

The thickness of the layer surfaced with one pass using EnDOtec DO*390N flux cored wire was $5.0 \div 5.2 \mathrm{~mm}$. Cracks with a width of $\leq 0.05 \mathrm{~mm}$ reaching the buffer were found in the padded layer.

The thickness of the layer surfaced with one pass using EnDOtec DO*02 flux cored wire was $3.5 \mathrm{~mm}$. The width of the buffer layer was $13.0 \mathrm{~mm}$. Single cracks with a width of $\leq 0.05 \mathrm{~mm}$ were found in the padded layer.

The thickness of the layer surfaced with one pass using EnDOtec DO*390N flux cored wire was $2.0 \div 2.2 \mathrm{~mm}$. The padding width was $2 \mathrm{~mm}$, therefore it was $1 \mathrm{~mm}$ smaller than the width of the buffer layer. Cracks with a width of $\leq 0.20 \mathrm{~mm}$ reaching the buffer were found in the padded layer.

The macroscopic examinations did not show the occurrence of unacceptable tears, whereas the occurrence of permissible cracks in the layers were found. In the padding welds there were also single gas pores, the size of which did not exceed $2 \mathrm{~mm}$, which is the permissible value according to PNEN ISO 15614-7:2016-12, pt. 8.1.1. An exemplary macrostructure of layers surfaced on sample plates of series 1 according to Table I has been shown in Figure 3.

In accordance with the requirements of PN-EN ISO 156147:2016-12, pt. 7.1. hardness tests were also carried out. The location of the measurement points is shown in Figure 4, while Table VI presents the results of tests of the layers surfaced on the sample plates of series 1 . The hardness of the upper layer of the plate No. 1 (one working layer) was

Table II. Conditions for side surface surfacing with HARDFACE HC-O cored wire

\begin{tabular}{|c|c|c|c|c|}
\hline $\begin{array}{c}\text { Current } \\
\text { intensity, A }\end{array}$ & $\begin{array}{c}\text { Arc } \\
\text { voltage, v }\end{array}$ & $\begin{array}{c}\text { Welding } \\
\text { speed, } \\
\text { cm/min }\end{array}$ & $\begin{array}{c}\text { Wire } \\
\text { extension, } \\
\text { mm }\end{array}$ & $\begin{array}{c}\text { Surfacing } \\
\text { stroke, } \\
\mathbf{m m}\end{array}$ \\
\hline $187 \div 205$ & $26.9 \div 27.3$ & 50.0 & $20 \div 22$ & 2.0 \\
\hline
\end{tabular}

Table III. Conditions of lateral surface hardfacing with EnDOtec $\mathrm{DO} * 390 \mathrm{~N}$ cored wire

\begin{tabular}{|c|c|c|c|c|}
\hline $\begin{array}{c}\text { Current } \\
\text { intensity, A }\end{array}$ & $\begin{array}{c}\text { Arc } \\
\text { voltage, } \mathbf{V}\end{array}$ & $\begin{array}{c}\text { Welding } \\
\text { speed, } \\
\mathbf{c m} / \mathbf{m i n}\end{array}$ & $\begin{array}{c}\text { Wire } \\
\text { extension, } \\
\mathbf{m m}\end{array}$ & $\begin{array}{c}\text { Surfacing } \\
\text { stroke, } \\
\mathbf{m m}\end{array}$ \\
\hline $165 \div 175$ & $23.0 \div 23.1$ & 50.0 & 18 & 2.0 \\
\hline
\end{tabular}

$691 \div 720 \mathrm{HV}$, while hardness of the plate No. 14 (four working layers) was 1010 $\div 1022 \mathrm{HV}$. The upper working layers of panels No. 21 and 24 had similar hardness. The tests have also shown that the hardness of the SWC does not exceed $380 \mathrm{HV}$, meeting the requirements of the PN-EN ISO 15614-7 standard, pt. 8.2.3.
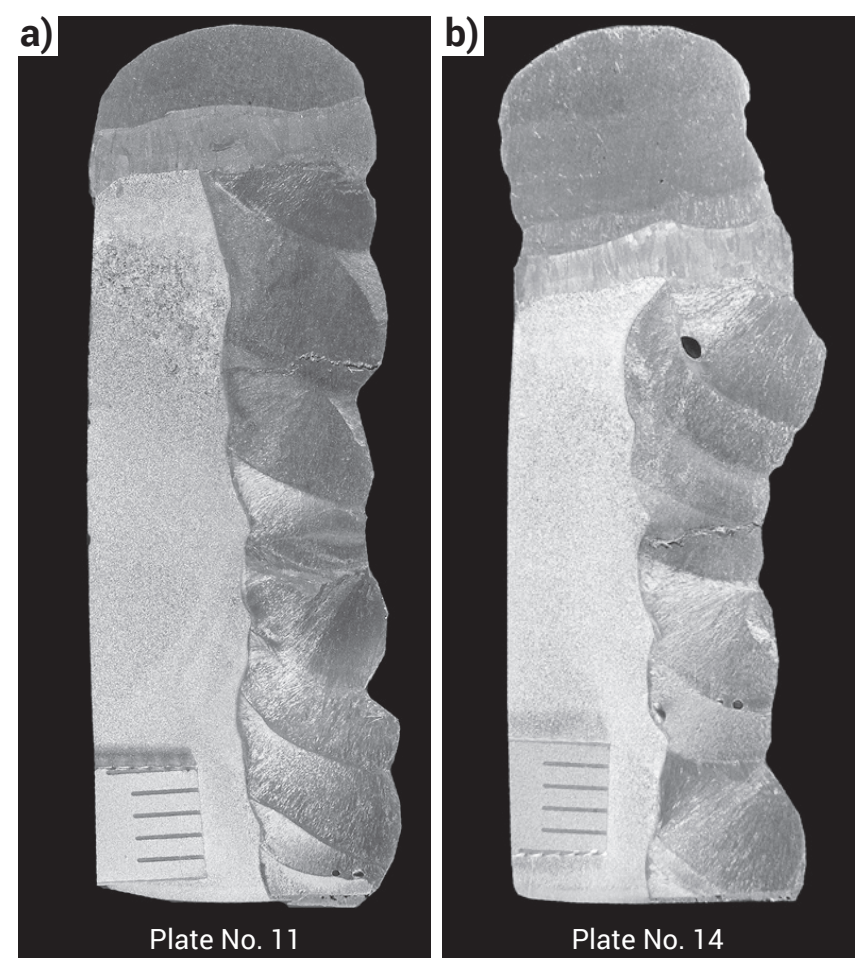

Fig. 3. Macrostructure of surfaced plates of series 1 (filler materials according to Table I) with the overlay weld on the face laid: a) in a single run - thickness $7 \mathrm{~mm}$ including the buffer layer; b) in a four runs - thickness $11.5 \mathrm{~mm}$ including the buffer layer

a)

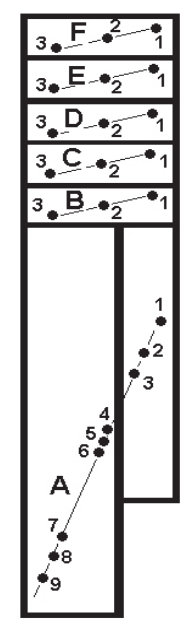

b)

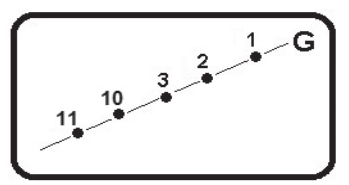

Table IV. Conditions of the buffer layer surfacing with EnDOtec DO*02 wire

\begin{tabular}{|c|c|c|c|c|c|}
\hline Current intensity, A & Arc voltage, $\mathbf{V}$ & $\begin{array}{c}\text { Welding speed, } \\
\mathbf{c m} / \mathbf{m i n}\end{array}$ & $\begin{array}{c}\text { Oscillation speed, } \\
\mathbf{m m} / \mathbf{m i n}\end{array}$ & $\begin{array}{c}\text { Amplitude } \\
\text { of oscillation, } \mathbf{m m}\end{array}$ & $\begin{array}{c}\text { Time of oscillation } \\
\text { stop, } \mathbf{s}\end{array}$ \\
\hline $197 \div 208$ & $20.8 \div 21.0$ & 25.0 & 1500 & 3.0 & 0.35 \\
\hline
\end{tabular}

Table V. Surfacing conditions of the face surface with EnDOtec DO*390N wire

\begin{tabular}{|c|c|c|c|c|c|}
\hline Current intensity, A & Arc voltage, $\mathbf{V}$ & $\begin{array}{c}\text { Welding speed, } \\
\mathbf{c m} / \mathbf{m i n}\end{array}$ & $\begin{array}{c}\text { Oscillation speed, } \\
\mathbf{m m} / \mathbf{m i n}\end{array}$ & $\begin{array}{c}\text { Amplitude } \\
\text { of oscillation, } \mathbf{m m}\end{array}$ & $\begin{array}{c}\text { Time of oscillation } \\
\text { stop, } \mathbf{s}\end{array}$ \\
\hline $145 \div 153$ & 23 & 22.0 & 1000 & 4.0 & 0.35 \\
\hline
\end{tabular}


Table VI. The results of hardness measurements of the surfaced test plates

\begin{tabular}{|c|c|c|c|c|c|c|c|c|c|c|c|c|}
\hline \multirow{3}{*}{$\begin{array}{l}\text { Plate } \\
\text { number }\end{array}$} & \multirow{3}{*}{$\begin{array}{l}\text { Test } \\
\text { line }\end{array}$} & \multicolumn{11}{|c|}{ Place of measurement according to figure 4 and hardness of HV10 } \\
\hline & & \multicolumn{3}{|c|}{ Padding weld } & \multicolumn{3}{|c|}{ HAZ } & \multicolumn{3}{|c|}{ Basic material } & \multicolumn{2}{|c|}{ Padding weld } \\
\hline & & 1 & 2 & 3 & 4 & 5 & 6 & 7 & 8 & 9 & 10 & 11 \\
\hline \multirow{5}{*}{11} & A & 592 & 707 & 642 & 134 & 130 & 136 & 136 & 136 & 135 & - & - \\
\hline & B & 333 & 354 & 348 & - & - & - & - & - & - & - & - \\
\hline & C & 665 & 724 & 715 & - & - & - & - & - & - & - & - \\
\hline & G & 720 & 691 & 710 & - & - & - & - & - & - & 700 & 716 \\
\hline & A & 606 & 508 & 536 & 145 & 135 & 132 & 123 & 123 & 118 & - & - \\
\hline \multirow{6}{*}{14} & B & 292 & 285 & 258 & - & - & - & - & - & - & - & - \\
\hline & C & 642 & 734 & 673 & - & - & - & - & - & - & - & - \\
\hline & D & 734 & 803 & 882 & - & - & - & - & - & - & - & - \\
\hline & E & 858 & 824 & 960 & - & - & - & - & - & - & - & - \\
\hline & $\mathrm{F}$ & 1018 & 1003 & 1033 & - & - & - & - & - & - & - & - \\
\hline & G & 1010 & 1018 & 1022 & - & - & - & - & - & - & 1032 & 1020 \\
\hline
\end{tabular}

\section{Conclusions}

On the basis of conducted technological tests and testing of welded elements, the following conclusions can be made:

1. Technological research of the surfacing of plates which simulate the conveyor coils after exploitation, with a side layer welded with chromium cast iron using HARDFACE HC-O flux cored wire, has shown the possibility of making the upper coil layer using EnDOtec DO*390N flux cored wire, one-, two-, three- and four-layer, on the buffer layer padded with EnDOtec DO*02 flux cored wire.

2. Technological research of the surfacing of plates which simulate the conveyor coils with a side layer productively welded using EnDOtec DO*390N flux cored wire, has shown the possibility of making the upper coil layer one-, two-, threeand four-layer on a buffer layer padded with EnDOtec DO*02 flux cored wire.

\section{Literatura}

[1] EnDOtec DO^390N - przykłady zastosowań, www.castolin.pl

[2] Е.А. Ледников, М.В. Радченко, Л.Б. Первухин, Наночастицы как модификаторы порошковой смеси для сверхзвуковой газопорошковой наплавки, Ползуновский вестник, vol. 11, № 1/1, c. 173-176, 2012, http://elib.altstu.ru/elib/books/Files/pv2012_01_1/pdf/173lednikov.pdf(dostęp 13.05.2018)

[3] I.A. Riabcew, Strukturalna dziedziczność w procesach napawania, Przegląd Spawalnictwa (2011), vol. 83 (10), 50-55.

[4] И.А. Рябцев, И.К. Сенченков, Э.В. Турык, Наплавка. Материалы, технологии, математическое моделирование, Wydawnictwo Politechniki Śląskiej, Gliwice, 2015.
[5] W. Napadłek, A. Laber, Badania wybranych właściwości wysokody spersyjnych napoin wytworzonych techniką laserową przeznaczonych na elementy maszyn o podwyższonej odporności na zużycie w warunkach tarcia, Tribologia (2010), vol. 41 (5), 21-36.

[6] A. Klimpel, T. Kik: Erosion and abrasion wear resistance of GMA wire surfaced nanostructural deposits, Archives of Materials Science and Engineering (2008), vol. 30 (2) april, 121-124.

[7] WA Cored Wires. Hardfacing, www.welding-alloys.com 